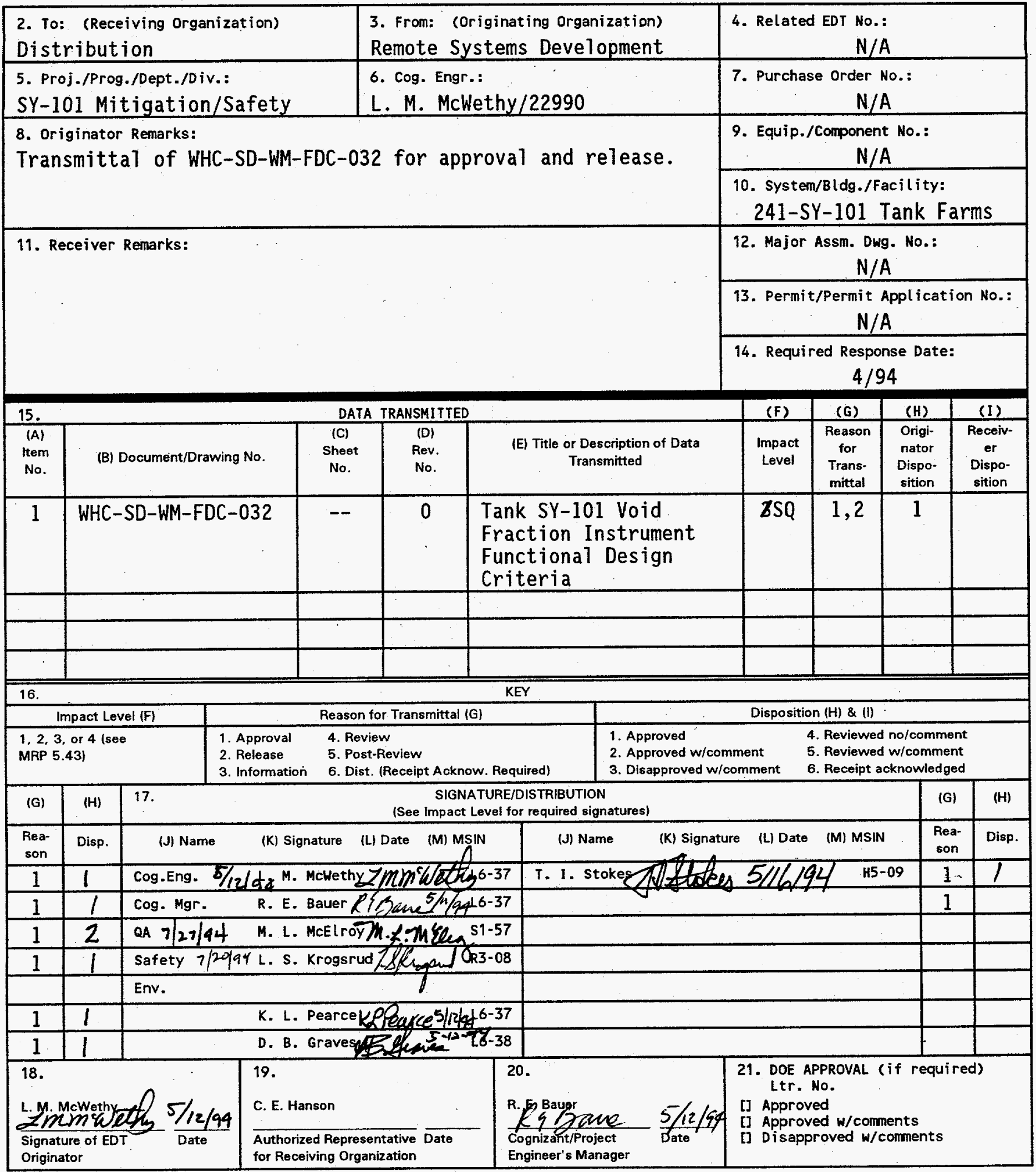

BD-7400-172-2 (07/91) GEF097 


\section{DISCLAIMER}

Portions of this document may be illegible in electronic image products. Images are produced from the best available original document. 


\section{RELEASE AUTHORIZATION}

Document Number: WHC-SD-WM-FDC-032, Revision 0

Document Title: $\quad$ Tank SY-101 Void Fraction Instrument Functional Design Criteria

Release Date: $\quad 10 / 17 / 94$

This document was reviewed following the procedures described in WHC-CM-3-4 and is:

APPROVED FOR PUBLIC RELEASE

WHC Information Release Administration Specialist:

M.Bostar

$10 / 17 / 94$

M.N. Boston

TRADEMARK DISCLAIMER. Reference herein to any specific comercial product, process, or service by trade name, trademark, manufacturer, or otherwise, does not necessarily constitute or imply its endorsement, recommendation, or favoring by the United States Government or any agency thereof or its contractors or subcontractors.

This report has been reproduced from the best ovailable copy. Avoilable in paper copy and microfiche. Printed in the United States of America. Available to the U.S. Departient of Energy and its contractors from:

U.S. Department of Energy

office of scientific and Technical Information (OSTI)

P.0. Box 62

Ook Ridge, TN 37831

Telephone: (615) 576-8401

Available to the public from:

U.S. Department of Commerce

Netional Technical Information Service (NTIS)

5285 Port Royal Road

Springfield, VA 22161

Telephone: (703) $487-4650$ 
2. Title

Tank SY-101 Void Fraction Instrument Functional Design Criteria

5. Key Words

SY-101

Void Fraction Instrument

Functional Design Criteria
3. Number

WHC-SD-WM-FDC-032
4. Rev No.

0
6. Author

Name: L. M. McWethy

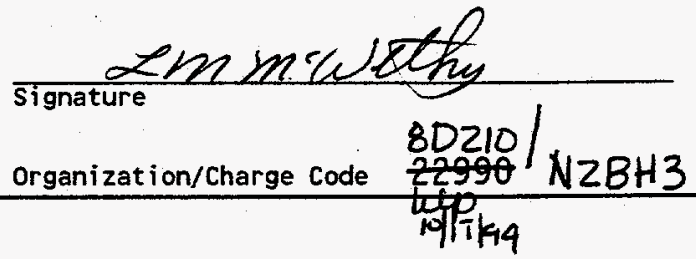

7. Abstract

This document presents the functional design criteria for design, analysis, fabrication, testing, and installation of a void fraction instrument for Tank SY-101. This instrument wi11 measure the void fraction in the waste in Tank SY-101 at various elevations.

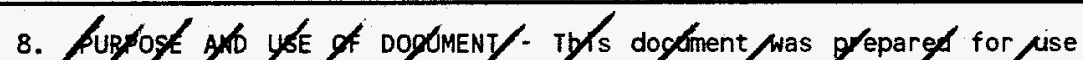
w/th/n the y.s. bepaptment/of Epergy ghd itg/contcactorg. it /s to *. be uged fonl tg perform, diregl, of integrate work under

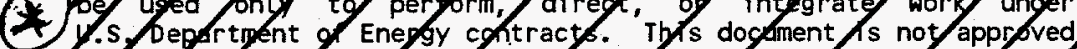
fo) public relerse uph il geviewer.

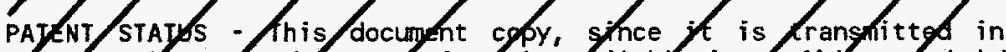
advapte of paterte clarance, is rade arailable in fonfiftence solely for use in performane of wory under contracks y/th the y.s. Departyent of Enepgy. This do ument is no to be published nor its fontents onerwife disgeminated or used for purpose othef than specifiza abple before grtent approyat for such/telege or/use has Ween securgd, upoh request, $\mathrm{f}$ om the Paten/ coysel o.s. Depar ment of Ehergy fielg offige, Righland/WA.

Disclimer/thits report as prepared as an actoun of work sporsored by an/agenc/ of the United stgtes Government. Neither the Wited/tated Govephment hor an/ aggncy thereof/ nor/any $6 \mathrm{f}$ their emplg/ees. Tor any of their fontractors/, sublontryctory or thej emoloyees make any warranty, express or iphlied, or assynes any legal liability or esponsjoility for the agcurag/. corpleteness, or any thrd porty's use or the results of sych use of ghy juforytion, appratus prodict, or process dishlosed, or epregents/thatits/use wpluld not inf inge polvatgly owped rights. Reforency herfin to any speciflc commercial product, proceds, of sep/ice/by trade nape. trademark manufacturer of otherwile, coes not necessafily cgistityte or juply jts endorsement, ecompendghion/or favoring by the ynited states Government or any agghcy thepof or its contractors or subcont actorf. The views and opinions of guthons expressed herejh do pot nelessafily atator oflatt thos of the United States Goverument of any agenty thereol.

9. Impact Level $B S Q$
10. RELEASE STAMP

OFFICIAL PELEASE

by

DATE OCT 181994

35 


\title{
TANK SY-101 VOID FRACTION INSTRUMENT FUNCTIONAL DESIGN CRITERIA
}

D. B. Graves

K. L. Pearce

L. M. McWethy

\section{DISCLAIMER}

\begin{abstract}
This report was prepared as an account of work sponsored by an agency of the United States Government. Neither the United States Government nor any agency thereof, nor any of their employees, makes any warranty, express or implied, or assumes any legal liability or responsibility for the accuracy, completeness, or usefulness of any information, apparatus, product, or process disclosed, or represents that its use would not infringe privately owned rights. Reference herein to any specific commercial product, process, or service by trade name, trademark, manufacturer, or otherwise does not necessarily constitute or imply its endorsement, recommendation, or favoring by the United States Government or any agency thereof. The views and opinions of authors expressed herein do not necessarily state or reflect those of the United States Government or any agency thereof.
\end{abstract}

\section{ABSTRACT}

This document presents the functional design criteria for design, analysis, fabrication, testing, and installation of a void fraction instrument for use on Tank SY-101. The void fraction instrument will determine the compressible gas fraction of the waste in Tank SY-101 at various elevations. It will be installed in a 4-inch penetration riser and be provided with a decontamination spray system for cleanup upon removal. 


\section{CONTENTS}

1.0 Introduction ................... . . 3

1.1 Background ................... 3

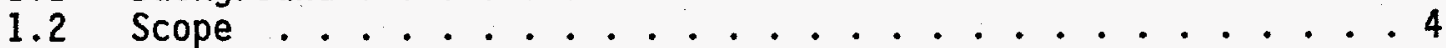

1.3 Site Location ................... . . 5

1.4 Project Interfaces . . . . . . . . . .....6

2.0 Project Criteria .................. 6

2.1 Functional Requirements .............6

2.2 Performance Requirements ............ 7

3.0 Process Criteria . . . . . . . . . . . . . 8

3.1 Instrumentation and Control ............. . 8

3.2 Piping and Vessels ................. . . . . . . . . .

3.3 General Chemical Process ...................11

3.4 General Mechanical Process . . . . . . . . . . . 12

4.0 Facility Criteria . . . . . . . . . . . . . . . . . . .

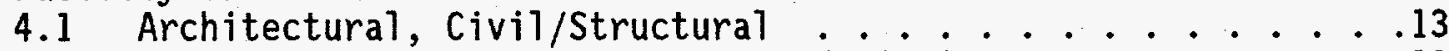

4.2 Heating, Ventilation, and Air Conditioning ........13

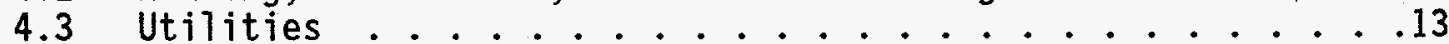

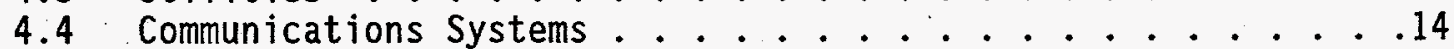

4.5 Automatic Data Processing . . . . . . . . . . . . 14

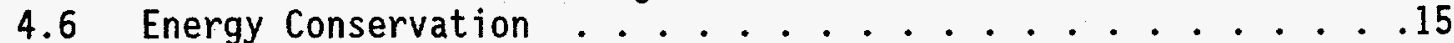

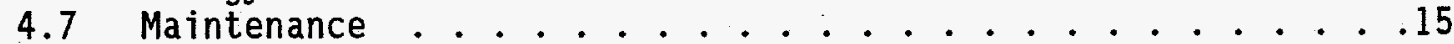

5.0 General Requirements . . . . . . . . . . . . . . 15

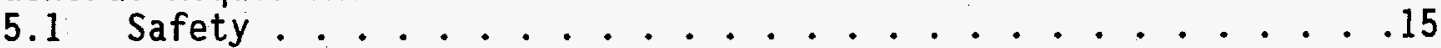

5.2 Environmental Protection and Compliance ................

5.3 Safeguards and Security .................. . . . . . . .

5.4 Natural Forces . . . . . . . . . . . . . . . . 18

5.5 Design Format . . . . . . . . . . . . . . . . . 19

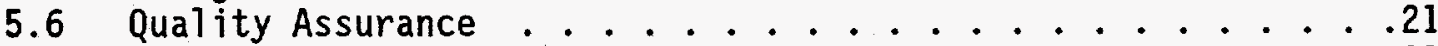

5.7 Decontamination and Decommissioning ...........21

5.8 Operating Personnel and Services .............22

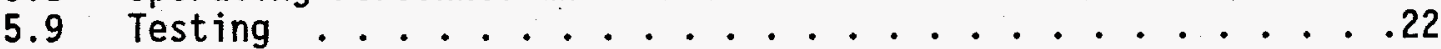

6.0 Codes and Standards . . . . . . . . . . . . . . 24

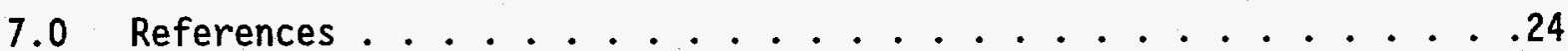

7.1 U.S. Department of Energy Headquarters . . . . . . . .24

7.2 U.S. Department of Energy, Richland ............24

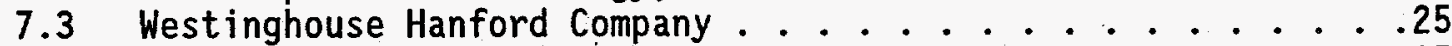

7.4 Los Alamos National Laboratory . . . . . . . . . . . .25

7.5 Codes and Standards ................... . . . . . .

8.0 Acronyms and Abbreviations . . . . . . . . . . . 26 


\section{TANK SY-101 VOID FRACTION INSTRUMENT \\ FUNCTIONAL DESIGN CRITERIA}

\subsection{INTRODUCTION}

\subsection{BACKGROUND}

Several studies of the periodic gas releases (some at flammable concentrations) from SY-101 have been performed with the ultimate goal of mitigating the safety concerns related to this tank. One of the safety controls limiting hydrogen mitigation activities is the maximum waste level (cannot currently exceed 408 inches) in the tank. Several waste parameters were evaluated in the safety assessment to determine this level control. These parameters include total volume of gas in the waste, location of gas and how it is retained, composition of the gas, volume of the released gas, and composition of the released gas.

Direct acquisition of any or all of the above data lends substantial credibility to current safety analys is work and to WHC's understanding of the gas release phenomenon. Such information may also be used to eliminate overconservatism in current safety-based controls. This development activity focuses on the WHC effort to directly obtain void gas volume. It is critical to recognize that the total gas trapped in the waste consists of void (bubble) gas, dissolved gases, and adsorbed gases. The term "void fraction" is defined as the percent of void gas volume per a given volume of waste.

Void fraction data of the waste in the nonconvective layer (NCL) is needed to enhance calibration of the computer models (TEMPEST). This computer model is used to predict the size of a gas release at any time under varying stimuli (such as waste level, installing a new pump, operating the pump, etc.). This release size is then tied to "burn" calculations. A larger release correlates to a larger burn accident.

Although some of the total gas volume may be trapped in the convective layer, it is assumed that most of the gas is trapped in the nonconvective layer. After a gas release event (GRE), the total volume of trapped gases remaining are expected to be distributed nonuniformly within the tank (elevation, radial position, time dependence). Some regions of the NCL may not have been agitated enough to release the trapped gases, while other regions of the NCL may have had most of the trapped gases released.

Therefore, void fraction data as a function of time and location in the tank will be key in understanding the nature of these gas releases. Void fraction data could also provide information on the rate of gas generation or the effectiveness of a given mitigation technique. Void fraction data will ultimately be used in dispositioning Tank SY-101's unreviewed safety question (USQ). 
Scoping calculations based on surface level change with changes in barometric pressure have been performed to estimate the total amount of void gas in the waste. However, the level of accuracy required was not acceptable with this method. Another method identified for obtaining void fraction data was a more detailed laboratory analysis from a core sampler. Because the core sampler does not have the capability of capturing a gas-tight waste sample, laboratory measurements of core samples to obtain the void fraction are not achievable.

In July 1993, a $150 \mathrm{Hp}$ test mixer pump was installed in SY-101 to test the effectiveness of mixing the waste to control the release of gas.

Continued operation of the test mixer pump is contingent on the waste surface level not exceeding the 408-inch level control. This level control is based on the assumption that the neutral buoyancy void fraction is 19 percent when the waste level is 415 inches. (Neutral buoyancy is the point at which the waste "rolls over" and the trapped gas is released.) The void fraction data currently being used is believed to be highly conservative, which accordingly increases TEMPEST gas release predictions. Therefore if the void fraction can be measured and shown to be less than the presumed 19 percent at 415 inches, the current 408-inch level operating 7 imit can justifiably be increased-allowing greater latitude in operating the pump.

With regard to previous work to obtain void fraction data, a design team consisting of personnel from Westinghouse Hanford Company (WHC) Characterization Equipment group, ICF Kaiser Hanford (ICF KH) Processing Projects Department, and Battelle Pacific Northwest Laboratory (PNL) Automation and Measurement Sciences Department executed and documented as study of potential sampling methods (WHC-SD-WM-WP-228, Rev. 0, "Evaluation and Preliminary Work Plan for Void Fraction Device"). A number of ideas were explored and discussed. Generally, the constraints considered were related to. operations in the SY-101 tank environment; judgment regarding the applicability and technical maturity of potential solutions guided the committee's selection process. From the work of this committee, two leading candidates and a vague set of criteria evolved. One of the concepts recommended for further development was the in situ void fraction instrument. This instrument would directly capture a waste sample and compress in situ to measure void fraction directly.

Therefore to support the effective mitigation of tank safety issues, an in situ void fraction instrument will be designed and fabricated. The proposed void fraction instrument will (when designed, fabricated, and tested) provide a method for measuring the amount of void gas in the tank waste. J.W. Lentsch, as the Project Manager of TWRS Hydrogen Mitigation Safety Project is the primary customer of this device. The primary goal of this instrument is to obtain data which will allow flexibility in the tank level control and reduce uncertainties regarding accidents and possible consequences.

\subsection{SCOPE}

This program will provide a tested and calibrated void fraction instrument that can repeatedly be used through 4-inch risers on the SY-101 tank to "capture" a known volume of waste from various locations within the 
tank. The device will pressurize the waste sample to provide the data necessary to analytically determine the void fraction of that sample.

The void fraction instrument is a remotely closable sample chamber deployed through a 4-inch riser to the desired depth in the tank. As the device penetrates the NCL, the waste will fill the chamber with as 1 ittle disturbance as possible. Once in position, a tube will slide over the sample chamber to seal the sample of waste. A pressurization chamber, previously filled with nitrogen to $500 \mathrm{psia}$, is then opened to the sample chamber. The pressure after these two chambers equalize is recorded. The sample chamber cover is then retracted and the waste pressure at that elevation is recorded. These two pressures, along with recorded temperatures of the system, allow the void fraction to be calculated. With the sample chamber open, the device is lowered to take another sample. This process is repeated until the entire $\mathrm{NCL}$ layer is sampled. Rotation to another angle allows for another vertical sampling run. Used in other risers, this process will measure void fractions in several locations in the tank.

Control of the void fraction instrument is from a temporary control cabinet placed outside the tank fence. Interconnecting cables are placed temporarily while the test is run.

A decontamination spray system is provided to clean waste from the device when it is withdrawn from the waste. This will minimize radioactive contamination on the lower end after use. A sealed shipping container will be used for moving between tank farms and for storage between use.

\subsection{SITE LOCATION}

The void fraction instrument will be located over any 4-inch riser or any riser adapted to accommodate the 4-inch riser interface requirements. Support systems for the instrument will be located outside the boundary fence in accordance with guidelines in DOE Order 6430.1a and DOE Field Office, Richland (RL) Order $4320.2 \mathrm{c}$. The site integration criteria are:

- Support subsystems of the void instrument not placed directly over the 4-inch riser shall be located to permit convenient connection to existing utilities and next to existing roadways.

- Support subsystems shall be located to minimize interference with existing facilities.

- Specific site factors to be evaluated in locating the support subsystems are:

-- Utilities/site services

-- Site interference

-- Environmental and safety considerations

-- Cost

-- Minimal operator exposure to radioactive and chemical hazards resulting from installation, operation, maintenance, calibration, and surveillance of the void instrument or support equipment

-- Minimal disruption of contaminated soil 
-- $\quad$ Static and dynamic loading imposed on Tank SY-101

-- Riser loads

\subsection{PROJECT INTERFACES}

The functional and physical interfaces with Tank SY-101 are:

- A decontamination spool piece (about 5 feet long) will bolt to the selected 4-inch riser on SY-101 during operation. The void fraction instrument will be inserted into the decontamination spool piece and the 4-inch riser, sliding through a rubber gasket on the spool piece to provide containment seal.

- Structural support for the void fraction instrument is normally provided by a crane, but if necessary, the weight of the void fraction instrument will be taken on the 4-inch riser.

The supporting subsystems for the void fraction instrument will

interface with existing tank farm systems, as necessary:

- Electrical supply for the void fraction instrument and the control console.

- Water supply for the decontamination spray system from a tank truck.

\subsection{PROJECT CRITERIA}

\subsection{FUNCTIONAL REQUIREMENTS}

The void fraction instrument shall meet the following criteria:

- The void fraction instrument shall be installed on existing risers on Tank SY-101 as needed for data collection; the first two selected are Risers $4 \mathrm{~A}$ and $11 \mathrm{~B}$.

- The void fraction instrument shall contain tank vapor/gas contents to the same degree as existing tank penetrations.

- The void fraction instrument shall be capable of measuring waste void fraction at vertical elevations from top of the convective layer to the bottom of the tank.

- The void fraction instrument shall include a decontamination system to assure decontamination to acceptable levels prior to removal from the riser. 


\subsection{PERFORMANCE REQUIREMENTS}

The void fraction instrument shall meet the following performance requirements:

- The void fraction instrument shall meet all safety, shielding, and environmental requirements for attachment to Tank SY-101.

- Loads applied to the tank riser used, the dome, and any ancillary support structures must not exceed any operating and design specifications for Tank SY-101 under normal operating conditions. Impact limiting devices shall be incorporated as required to protect the tank and riser(s).

- A7. materials, equipment, and instruments exposed to the tank vapor space shall be nonsparking, grounded, or bonded to prevent electrical sparks to satisfy Hazard Class 1, Division 1, Group B requirements.

- The installation, operation, and removal of the void fraction instrument shall not adversely affect the ventilation and cooling system on Tank SY-101.

- The void fraction instrument shall be contoured to allow "snag-free" removal.

- In an emergency such as a bent void fraction instrument stalk, special safe shutdown hardware shall be ready to lower the void instrument to near-tank bottom--assuring that the void fraction instrument is in a safe shutdown condition and permitting continued normal operation of Tank SY-101.

- Materials of construction shall be compatible with their environments. Series 300 stainless steel shall be used for structural components as much as practical. All materials exposed to tank liquid waste or tank vapor shall not deteriorate during the design life of the components and shall have surfaces which do not retain excess contamination during water wash before removal.

- Outside diameter of the instrument shall be no greater than 3.60 inches. Concentricity of diameters shall be maintained to assure clearance in any riser used.

- The void fraction instrument shall be capable of being deployed through the salt cake on top of the waste. Use of a water lance to create a hole through the waste crust shall be considered as a contingency.

- Design, installation, operation, maintenance, and removal of the void fraction instrument shall minimize exposure of personnel to radiation, chemical, and physical hazards. 
- The design of the void fraction instrument shall not preclude retrieval of a trapped sample from the tank, if practical. Additional design features may have to be added 7 ater.

- The void fraction instrument should be capable of taking void fraction measurements at least every 2 feet vertically in the tank waste at two angles in an 16-hour shift. At least 100 measurements should be made between maintenance actions.

- The waste pressurization line shall be flushed with water and blown dry after each test day to assure against blockage from dried waste.

- The void fraction instrument should be able to operate under any weather conditions permitting routine work on the tank farm.

\subsection{PROCESS CRITERIA}

\subsection{INSTRUMENTATION AND CONTROL}

\subsubsection{Functional Requirements}

Instrumentation and control(I\&C) for the void fraction instrument shall perform the following functions:

- Rotate the forearm from vertical to $90^{\circ}$ and back again.

- Close and open the sample chamber cover.

- Pressurize the pressurization chamber.

- Open the pressurization chamber to the closed sample chamber.

- Measure the pressurization chamber and line pressures.

- Measure the waste temperature at the elevation of the sample chamber when in the deployed position.

- Measure the temperature of the line connecting the pressurization chamber and the sample chamber.

- Measure the temperature of the pressurization chamber.

- Monitor the performance of the pneumatic cylinders causing rotation of the forearm and the movement of the sample chamber cover.

- Pressurize the water tank. 
- Open and close the water tank outlet valve to wash the check valve located at the sample chamber.

\subsubsection{Performance Requirements}

The I\&C system shall meet the following performance requirements:

- Primary monitoring and control of the void fraction instrument shall take place at the remote control console, located outside the radiologically-controlled zones surrounding the SY-101 tank as much as possible to allow for ease of maintenance and access.

- The I\&C functions shall be designed to meet the applicable hazards classification (see Section 4.3.4).

- The pressure of the pressurization chamber should be measured with redundant pressure transducers with accuracies of \pm 0.5 percent or better.

- The temperature of the pressurization chamber should be measured with redundant TCS with accuracies of $\pm 1^{\circ} \mathrm{F}$ or better.

- The line connecting the pressurization chamber with the sample chamber should be monitored with a pressure transducer with accuracy of $0.5 \mathrm{psi}$ or better and with three thermocouples with accuracy of $\pm 1^{\circ} \mathrm{F}$ or better.

- The waste temperature at the sample chamber elevation should be monitored with redundant thermocouples with accuracy of $\pm 1^{\circ} \mathrm{F}$ or better.

- Maintain the temperature of critical I\&C components at least $40^{\circ} \mathrm{F}$, including the pressurization chamber and its instruments, the nitrogen supply cylinder, and the water tank.

- Monitor the temperature of the critical I\&C components.

- Monitor the elevation of the void fraction instrument.

- Monitor pressure and flow rate to the pneumatic cylinders.

- Monitor pressures both upstream and downstream of the pressure regulators.

- Monitor pressure of water tank.

- Low-voltage instrument wires shall not be located in the same junction box with higher voltage electrical leads. 


\subsection{PIPING AND VESSELS}

\subsubsection{Functional Requirements}

The piping and vessels of the void fraction instrument shall meet the following functional requirements:

- The void fraction instrument shall slide through a wiper seal on the decon spray system (which shall itself be sealed to the SY-101 riser) which shall contain the vapor and gases of the tank environment. Both seal functions shall be performed during all normal operating conditions and for all expected environmental conditions.

- The support mast (a 3 -irich SCH 80 pipe) shall be a drywell with the bottom end welded leak-tight. The bulkhead shall provide welded penetrations for the cylinder supply lines and the thermocouples wells. The thermocouple wells shall be sealed to the thermocouples (welded, brazed, potted, or Swagelocks). Design shall assure that no waste can become trapped within the mast even if the lines, immersed in the waste, should be broken.

- The void fraction instrument shall be sealed between the sampling arm and the support mast to preclude any movement of waste to the instrument and control enclosure above ground.

- A decontamination spray system shall be provided to wash back into Tank SY-101 any waste which may be on the support mast or the sampling arm. This wash function shall be used on each upward movement as required or on removal of the void fraction instrument from the tank.

- Provide a bolted flange connection on the support mast just below the I\&C containment for weather-tight temporary storage of the contaminated mast and sampling arm separate from the I\&C containment.

- Provide a connection to the pressurization chamber to permit measurement of the pressurization chamber volume to an accuracy of 0.1 percent and the volumes of the chamber pressurizing line and the sample chamber to an accuracy of 1 percent.

- Provide a pressurization chamber, sample chamber, and chamber pressurizing line that can be used to measure the void fraction of the waste.

- Provide a water wash system to flush the chamber pressurizing line and the sample chamber check valve when necessary. 


\subsubsection{Performance Requirements}

The piping and vessels of the void fraction instrument shall meet the following performance requirements:

- Provide a pressurization chamber, rated at $500 \mathrm{psia}$, with a volume of approximately 5 cubic inches (including all instrumentation) between the closed inlet and exit solenoid valves. Provide inlet and exit solenoid valves and an exit line check valve. Do not provide any vent lines to this system to assure against leakage affecting the measurement accuracy.

- Provide a sample chamber, rated at 500 psia, with a volume of 22 cubic inches (including the downstream portion of the check valve). Include a check valve just upstream of the sample chamber to prevent back-flow of waste into the chamber pressurizing line.

- Provide a connecting line between the pressurization chamber and the sample chamber with minimum volume, sized to assure that the peak pressurization rate of the sample chamber is less than $100 \mathrm{ps} i / \mathrm{second}$.

- Provide a water tank holding at least 1 gallon of water and having a gas space of at least 50 cubic inches. Pressurize this tank to 200 psia. Valve this tank into the chamber pressurizing line to wash the sample chamber check valve when necessary. Provide an exit check valve to prevent back-flow of gas into the water system. Provide a means to fill, vent, and drain the water tank.

- Provide a G3-size nitrogen supply cylinder (rated for 40 cubic feet) at $2200 \mathrm{psia}$. Provide a pressure transducer to monitor the nitrogen supply. Provide a manual shutoff valve, a pressure regulator providing 600 psia nitrogen, and a pressure transducer on the downstream side. Maintain this cylinder at $40^{\circ} \mathrm{F}$ (minimum) to minimize temperature changes in the pressurization chamber for at least 2 hours prior to any test.

- Provide nitrogen supply lines to both dual action pneumatic cylinders. Size these lines to allow smooth but not rapid piston action or provide a needle valve to control nitrogen flow.

- Provide pressure relief valves downstream of all regulators and on the drive-out line for the rotation cylinder.

- Provide a common vent to atmosphere for exhausting nitrogen from the pneumatic cylinders, exiting through a HEPA filter to atmosphere.

\subsection{GENERAL CHEMICAL PROCESS}

N/A 


\subsection{GENERAL MECHANICAL PROCESSES}

\subsubsection{Functional Requirements}

The void fraction instrument shall meet the following functional requirements:

- Position the void fraction instrument directly above the selected riser and lower carefully into the riser with minimum mechanical interference.

- Raise and lower the void fraction instrument in the tank as needed to position the instrument at the desired elevation.

- Rotate the forearm from a vertical to horizontal position after the arm is below the surface of the convective layer.

- Rotate the forearm from horizontal to vertical position on demand. Provide a spring to return the arm to vertical if pneumatic control is 10st. Provide pneumatic power to return the arm to vertical if the spring power is not sufficient to overcome friction.

- Provide a double-acting pneumatic cylinder to slide the sample chamber cover over the sample chamber and return to an open position. Provide a spring to return the cover to the open position if pneumatic power is 10st. Provide pneumatic power to open the cover if friction prevents the spring from opening the cover.

\subsubsection{Performance Requirements}

The void fraction instrument shall meet the following mechanical performance requirements:

- The forearm shall be rotated into position and returned to vertical by a pneumatic cylinder. The rotation speed will be controlled to prevent hard impact on the mechanical stops. The rotation time will be at least 5 seconds.

- Provide protection against overpressure in the rotation cylinder if on raising the void fraction instrument, an obstruction were to force the forearm from a horizontal to a vertical position.

- The sample chamber cover shall be opened and closed by a pneumatic cylinder. The cover opening and closing rate will be at least 5 seconds.

- Provide means to replace or recharge the nitrogen supply cylinder while the void fraction instrument is either in a horizontal or vertical position. 
- Provide means to refill or drain the water tank while the void fraction instrument is either in a horizontal or vertical position.

- Provide tapered surfaces where the void fraction instrument might encounter restrictive sharp edges in the tank riser or the decon spray system.

\subsection{FACILITY CRITERIA}

\subsection{ARCHITECTURAL, CIVIL/STRUCTURAL}

$N / A$

\subsection{HEATING, VENTILATION, AND AIR CONDITIONING}

The I\&C containment box containing the nitrogen supply cylinder, the pressurization chamber, and the water tank shall be heated to at least $40^{\circ} \mathrm{F}$ to allow operation in all anticipated environmental conditions.

The I\&C containment box containing the electronics shall be provided with a fan to provide cooling air flow to all electronic components.

\subsection{UTILITIES}

\subsubsection{Steam}

N/A

\subsubsection{Water}

Water for the decon spray system on the 4-inch riser shall be provided from a water truck. Nine gpm of demineralized water at 3000 psig are recommended at the pump outlet. Water temperature at the truck sha11 be nominally $130^{\circ} \mathrm{F}$ maximum.

\subsubsection{Sewage}

N/A

\subsubsection{Electrical}

Electrical service required for the void fraction instrument shall all be supplied from the control console. Existing tank electrical service 
outlets will be used for these requirements. Power requirements will be defined during the detail design stage.

The hazard classification developed for Tank SY-101 (Merriman, 1994) will be applied to the void fraction instrument installation, operation, and removal. The void fraction instrument will be installed, operated, or removed during any periods when Tank SY-101 operating conditions permit. The hazard classification used for void fraction instrument design will be:

\begin{tabular}{|l|l|}
\hline \multicolumn{1}{|c|}{ LOCATION } & \multicolumn{1}{|c|}{ HAZARD CLASSIFICATION } \\
\hline Liquid Waste & Class 1, Division 2, Group B \\
\hline Vapor Space & Class 1, Division 1, Group B \\
\hline Outside Riser & Class 1, Division 2, Group B \\
\hline
\end{tabular}

All electrical components and their installation shall adhere to the requirements of this electrical classification.

The electrical design shall be in compliance with DOE Order 6430.1a. Electrical designs and drawings shall be per Hanford plant standards design criteria and WHC-CM-6-3, "Drafting Standards Manual Design Criteria."

Installation of electrical components shall be per NFPA 70.

\subsubsection{Lighting}

Installation, operation, and removal of the void fraction instrument should occur only during daylight hours. Outdoor lighting will be required if a night installation is performed.

\subsection{COMMUNICATION SYSTEMS}

Standard issue radio communication devices will be used during installation, operation, and removal of the void fraction instrument to coordinate operations between the control console, the crane operator, the ground crew, and DACS.

\subsection{AUTOMATIC DATA PROCESSING}

A stand-alone computer and associated peripherals will be used for the operation of the void fraction instrument. This same computer system will also be used for the operation of the viscometer. A11 analog-to-digital signal processing will be accomplished on the void fraction instrument itself, in electronic components adjacent to the I\&C cabinet. Transmission of digital 
signals from the void fraction instrument to the computer console will be by infrared signals or alternately by hardwire connections.

\subsection{ENERGY CONSERVATION}

$N / A$

\subsection{MAINTENANCE}

\subsubsection{Facility}

The computer console is a temporary installation which will not require long-term maintenance.

\subsubsection{Equipment}

The void fraction instrument shall be designed to permit routine maintenance activities with minimum operator exposure to hazardous or radioactive environments or to industrial hazards. As low as reasonably achievable (ALARA) practices shall be used in all maintenance activities. The void fraction instrument I\&C containments shall be designed to permit access to all components requiring maintenance--in particular those components requiring adjustment, replacement, or filling such as nitrogen cylinder and water tank.

\subsubsection{Materials}

Materials required for maintenance of the void fraction instrument shall be identified and supplied prior to installation.

\subsection{GENERAL REQUIREMENTS}

\subsection{SAFETY}

\subsubsection{Criticality}

$$
N / A
$$

\subsubsection{Safety Analysis Requirements}

The void fraction instrument will be operated only during periods when a hydrogen burn hazard does not exist. Under these conditions, there are no 
Safety Class 1 functions associated with the operation of the void fraction instrument. Operation of the void fraction instrument is Safety Class 3 to assure safety to the operators. Prevention of spark/ignition sources during operation of the void fraction instrument shall be a Safety Class 2 process.

To allow removal of the void fraction instrument in case hydrogen control is lost in Tank SY-101, a grounding line from the I\&C containment to the riser will be required. This will prevent static electricity buildup during insertion or removal operations. This grounding line function is a Safety Class 2 function.

The installation, operation, and removal of the void fraction instrument must not cause damage to the primary tank or to any peripheral component judged to be Safety Class 1 or 2. Damage to the primary tank, the riser in use, or to the Safety Class 1 pressure release function of the multiport riser assembly (if used) must be prevented by design or precluded by administrative procedures.

Installation, operation, and removal of the void fraction instrument may be Safety Class 1,2 , or 3 depending on safety analys is to determine the risk of damaging Safety Class 1 or 2 equipment.

\subsubsection{Contamination Control}

The void fraction instrument has pressurized lines from the nitrogen source in the I\&C enclosure to the liquid waste space. The following contamination control requirements shall be met:

- The pressurization system for the sample chamber shall not be exhausted to atmosphere. Any possible connection with the atmosphere must be prevented by one active and one passive component (such as one solenoid valve and one check valve).

- The pneumatic cylinders to be operated in the liquid waste are operated by nitrogen supplied by four gas 1 ines. The design of these components must assure that 1iquid waste cannot be moved from the tank to the I\&C containment by any expected and undetected failure modes.

- The components of the void fraction instrument which may be exposed to liquid waste shall be constructed of materials which minimize the potential for contamination to reduce the efforts needed in decontamination and decommissioning.

- The void fraction instrument shall have a water spray to permit water spray decontamination as the instrument is moved up or is withdrawn from the tank.

- The void fraction instrument shall be nominally leak-tight under normal tank design conditions to minimize in-leakage of air and prevent back-diffusion of tank vapor and gas contents. The allowable leakage of 
tank vapors and gases during normal operation shall be identified during detail design. Equipment and surfaces at the points of potential leakage shall be designed to minimize contamination potential and for ease of cleanup.

- The support mast shall be sealed to assure no gas or vapor escape paths exist out of the tank. The gas lines and thermocouple wells shall be seal welded to bulkheads at the bottom of this structural pipe to assure zero leakage even if the gas lines and thermocouples were to break below the liquid waste level.

- Seal against gas leakage from the dry well at the top of the mast.

\subsubsection{Shielding}

- Shielding shall be incorporated as necessary into the void fraction instrument to achieve ALARA requirements. As a minimum, void meter should shield enough to avoid local radiation levels from exceeding $100 \mathrm{mr} /$ hour and having to designate the area a high radiation zone.

- Any part of the void fraction instrument which must be accessed routinely for operation, maintenance, or surveillance needs to be shielded as much as practical. The goal is to reduce local radiation levels to $0.2 \mathrm{mr} /$ hour.

\subsubsection{Industrial Safety}

Uprighting may be done with two mobile cranes. The raising and lowering of the void fraction instrument are accomplished using mobile cranes. The procedures used in these operations must meet all applicable industrial safety standards. In addition, the possibility exists for the instrument to contact waste bergs in the tank or to encounter stiff resistance to moving through the waste. These possibilities shall be monitored with a load cell on the crane to alert the crane operator, the ground crew, and the experimenters to possible hazardous conditions or conditions which might result in damage to the instrument. Procedures developed for installation, operation, and removal of the instrument shall meet all applicable industrial safety standards and shall be detailed and approved prior to instrument installation. Critical lifts shall be per DOE-RL-92-36, "Hanford Site Hoisting and Rigging Manual."

\subsubsection{Fire Protection}

The design and operating procedures of the void fraction instrument and its computer console shall be reviewed and approved by Fire Protection personnel to assure meeting all applicable fire protection standards prior to installation. 


\subsubsection{Traffic Safety}

A11 applicable traffic safety standards shall be met while transporting any component of the void fraction instrument.

\subsection{ENVIRONMENTAL PROTECTION AND COMPLIANCE}

The applicable environmental requirements for new and modified facilities, as defined in Section 9 of WHC-CM-7-5, "Environmental Compliance Manual," shall be identified and followed.

\subsection{SAFEGUARDS AND SECURITY}

No special safeguard and security requirements are needed beyond those currently in force. Control of personnel at the Hanford site barricades is deemed adequate.

\subsection{NATURAL FORCES}

Each of the following naturally-occurring scenarios shall be considered during design and safety analysis of the void fraction instrument.

\subsubsection{Design Basis Earthquake}

Safety Class 1,2 , and 3 items shall be designed to survive a design basis earthquake (DBE) as defined in HPS-SDC-4.1. Safety Class 4 items shall be designed in accordance with the Uniform Building Code as stated in HPS-SDC-4.1. Features necessary to maintain the mitigation systems and waste tank in a safe condition without undue risk to the health and safety of the public shall be Safety Class 1 items. The spectra given in HPS-SDC-4.1 shall be utilized in designing the facility and/or equipment for a design basis earthquake. The void instrument requires no special seismic analysis, but any feasible interaction with Safety Class 1 or 2 items during a DBE shall be analyzed sufficiently to show no reduction of safety.

\subsubsection{Design Basis Wind}

A11 equipment and features necessary to protect onsite personnel and the public shall be designed to withstand the 100-year recurrence interval wind loading according to HPS-SDC-4.1. 


\subsubsection{Design Basis Flood}

The elevation of the 200 area site has been judged to be outside the maximum extent of the Hanford site design basis flood.

\subsubsection{Volcanic Eruptions}

Features of the void fraction instrument which are deemed to affect tank Safety Class 1 and 2 functions should be designed to accommodate the effects of a volcanic eruption, including ash resulting from volcanic eruption according to HPS-SDC-4.1.

\subsubsection{Design Basis Power Failure}

In the event of a design basis power failure (i.e., loss of power), the void fraction instrument shall be maintained in a safe condition without undue risk to the health and safety of the public and onsite personnel.

\subsubsection{Design Basis Fire}

In the event of a design basis fire, the void fraction instrument shall be maintained in a safe condition without undue risk to the health and safety of the public and onsite personnel.

\subsection{DESIGN FORMAT}

Two-way traceability shall be provided between project drawings and the reference drawings from which they were developed. Project drawings shall. identify existing drawings that will be affected by the project.

Design drawing formats shall be in accordance with:

- WHC-CM-6-1, "Standard Engineering Practices," EP-1.3, "Preparation of Engineering Drawings."

- WHC-CM-6-3, "Drafting Standards Manua1."

\subsubsection{Drawing Requirements for 241-SY-101 Outline}

1. All drawings shall be created where one Autocad unit equals 1 inch. 
2. Drawings shall be set as follows:

\begin{tabular}{|c|c|c|c|c|}
\hline \multirow{2}{*}{ SCALE } & \multirow{2}{*}{ DIMSCALE } & \multirow{2}{*}{ LTSCALE } & \multicolumn{2}{c|}{ DTEXT HEIGHT } \\
\cline { 4 - 5 } & & & $1 / 8$ & $1 / 4$ \\
\hline Fu11 & 1 & .375 & .125 & 0.25 \\
\hline $1 / 2$ & 2 & .750 & 0.25 & 0.50 \\
\hline $1 / 4$ & 4 & 1.50 & 0.50 & 1.0 \\
\hline $1 / 8$ & 8 & 3.0 & 1.0 & 2.0 \\
\hline $1 / 16$ & 16 & 6.0 & 2.0 & 4.0 \\
\hline $1 / 2^{\prime \prime}=1^{\prime}-0^{\prime \prime}$ & 24 & 9.0 & 3.0 & 6.0 \\
\hline $1 / 4^{\prime \prime}=1^{\prime}-0^{\prime \prime}$ & 48 & 18.0 & 6.0 & 12.0 \\
\hline $1 / 8^{\prime \prime}=1^{\prime} 0^{\prime \prime}$ & 96 & 36.0 & 12.0 & 24.0 \\
\hline
\end{tabular}

Scales not shown above shall be approved by the lead designer prior to use.

3. All drawings shall have drawing numbers assigned by the lead designer.

4. Attributes shall not be used on this project.

5. XREFS shall not be used on this project.

6. Text style named STANDARD shall have text fonts set to Romans. Text style RD shall be created and set to text font Romans. Text styles STANDARD and RD shall be the only styles used on this project. Any deviation shall be approved by the lead designer.

7. PLINES shatl be used only in special cases.

8. All drawings shall have a date within the title block. The date shall be revised each time the dataset is updated.

9. Drawings shall be plotted to $8.5 \times 11$ after each drawings session and given to the lead designer. The lead designer shall maintain a logbook of all project drawings and a current copy of the drawings.

10. All drawing modifications and alterations (i.e., per design change) shall be done through the lead designer.

11. Drawing datasets shall be maintained through the lead designer prior to release. All datasets shall be checked out by the lead designer.

12. Drawings sha71 be created to the current revision of WHC-CM-6-3, Level III.

13. Layers shal1 be used and set per WHC-SD-GN-UM-30005, "Autocad Discipline Layering Conventions." 
14. Drawings shall only be modified per engineering-controlled redline markups after the drawings are submitted to the fabrication shops.

\subsection{QUALITY ASSURANCE}

Quality assurance/control activities for all contractors involved in design, construction, and acceptance testing shall be executed in accordance with the project-specific Quality Assurance Program Plan (QAPP) in WHC-EP-0550.

The basis for establishing quality assurance program requirements is safety classification as defined in WHC-CM-1-3, "Management Requirements and Procedures," MRP 5.46, "Safety Classifications of Systems, Components, and Structures." The safety classifications of items provides a graded approach to application of quality requirements. This graded approach assigns requirements to items commensurate with the function of each system, component, and structure in preventing or mitigating the consequences of hazards and postulated design basis accidents.

\subsection{DECONTAMINATION AND DECOMMISSIONING}

The design of the void fraction instrument and its associated systems shall facilitate decontamination so that the assembly can be decommissioned at a future date. Guidance for retrieval equipment design to facilitate eventual decommissioning shall be obtained from ANSI N300 and DOE Order 6430.1a, Sections 1300-11.2 and 1321-7.

The following principles shall be employed to the extent practical:

- Modular, separable confinements for radioactive and other hazardous materials shall be used to preclude contamination of fixed portions of structure.

- Exhaust filtration components of exhaust systems shall be located at or near affected components to minimize long runs of internallycontaminated tubing.

- Areas subject to contamination shall be designed to facilitate decontamination. Liners and coatings shall be selected to withstand decontaminating agents and radiation degradation throughout the project 1 ife.

- Penetrations shall be designed to minimize technical and mechanical problems associated with closing and sealing at the time of decommissioning.

- Surfaces should be free of crevices, ledges, and/or protrusions which could collect radioactive material. 
- Penetrations shall be waterproofed for protection during decontamination efforts.

- Fixtures and outlets shall be sealed.

- Drains and similar piping shall have physical provisions for cleaning.

- Piping systems shall be sloped and free of traps except as required for retrieval process isolation.

- Use of lifting lugs compatible with existing equipment is preferred.

The project design shall minimize hazardous and nonhazardous waste generation and use of hazardous materials during construction, operation, decontamination/decommissioning, and Resource Conservation and Recovery Act (RCRA) closure. Materials which are designated as hazardous or will be designated as hazardous waste at disposal shall be documented by the project on drawings or other design media as appropriate.

Where lead or similar hazardous materials are used for shielding or other purposes, the item shall be encapsulated to prevent radioactive contamination and to allow retrieval in an uncontaminated condition. The item shall be permanently marked as to its contents.

\subsection{OPERATING PERSONNEL AND SERVICES}

The void fraction instrument requires no permanently assigned personnel for installation, operation, or removal. Personnel conducting these operations shall be trained in a]l safety aspects of operating in the SY-101 environment and the void instrument equipment. All required personnel protective gear shall be used at times when working on or near the void fraction instrument. Confirmation of an acceptable radiation atmosphere shall be provided by Health Physics before any operation on the instrument is permitted.

Operation of the decon spray system is performed remotely by opening the required water spray valves. Local control is not planned for these operations.

\subsection{TESTING}

Acceptance testing of the void fraction instrument shall be accomplished to assure compliance with these functional and performance requirements. Testing will be in accordance with an approved acceptance test plan. Quality Assurance will verify acceptance testing as required. 


\subsubsection{Decontamination Spray System}

The decontamination spray system shall be tested to assure supplying enough water volume and with uniform distribution to assure adequate cleaning of the void fraction instrument on removal from a riser. A letter report documenting the procedure used and the test results shall be generated.

\subsubsection{Sample Chamber Pressurization}

The nitrogen system designed to pressurize the sample chamber shall be tested to assure against leaks, pressurization rates too high, and assure that pressure equalization with the pressurization chamber occurs in a reasonable time. The system shall be tested in air and in water. A letter report documenting the results shall be generated.

\subsubsection{Pneumatic Cylinder Operation}

The pneumatic cylinders shall be tested to assure against leaks, to assure moving the forearm and the sample chamber cover at the desired speed, and to assure that no hard impacts occur on either stroke. If nitrogen flow rate valving is required to achieve the desired cylinder speed, the required valve settings shall be secured.

\subsubsection{Water Wash System}

The water wash system designed to clear a plugged check valve on the sample chamber shall be tested to assure proper operation without leaks and delivery of sufficient water to clear the check valve. The results of these tests shall be used in developing the operating procedures for the instrument. 


\subsection{CODES AND STANDARDS}

Use of codes and standards identified below shall be considered.

\begin{tabular}{||l|l||}
\hline ANSI & $\begin{array}{l}\text { Design Criteria for Decommissioning of Nuclear Fuel } \\
\text { Processing Plant, ANSI N300, American National } \\
\text { Standards Institute, Washington, D. C. }\end{array}$ \\
\hline ASME & $\begin{array}{l}\text { Boiler and Pressure Vessel Code, ASME, Section VIII, } \\
\text { Division I, "Pressure Vessels, American Society of } \\
\text { Mechanical Engineers, New York, New York }\end{array}$ \\
\hline NFPA-70 & $\begin{array}{l}\text { National Fire Protection Association, Batterymarch } \\
\text { Park, Quincy, Massachusetts }\end{array}$ \\
\hline NFPA 497A & $\begin{array}{l}\text { Recommended Practice for Classification of Class 1 } \\
\text { Hazardous (Classified) Locations for Electrical } \\
\text { Installations in Chemical Process Areas }\end{array}$ \\
\hline OSHA & $\begin{array}{l}\text { Occupational Safety and Health Administration } \\
\text { Standards, Occupational Safety and Health } \\
\text { Administration, Washington, D. C. }\end{array}$ \\
\hline WISHA & $\begin{array}{l}\text { Washington Industrial Safety and Health Act, Safety and } \\
\text { Health Standards, Washington Industrial Safety and } \\
\text { Health Act, Olympia, Washington }\end{array}$ \\
\hline
\end{tabular}

\subsection{REFERENCES}

\subsection{U.S. DEPARTMENT OF ENERGY HEADQUARTERS}

\begin{tabular}{|l|l|}
\hline DOE 5700.6c & Quality Assurance, Washington, D. C. \\
\hline DOE 6430.1a & Genera7 Design Criteria, Washington, D. C. \\
\hline
\end{tabular}

\subsection{U.S. DEPARTMENT OF ENERGY, RICHLAND OPERATIONS OFFICE}

\begin{tabular}{|l|l|}
\hline RL 4320.2c & Site Selection, Richland, Washington \\
\hline HPS-SDC-4.1 & Standard Architectural - Civil Design Criteria, Rev. 11 \\
\hline RL-92-36 & Hanford Site Hoisting and Rigging Manual \\
\hline
\end{tabular}




\subsection{WESTINGHOUSE HANFORD COMPANY}

\begin{tabular}{||l|l||}
\hline WHC-CM-1-3 & $\begin{array}{l}\text { Management Requirements and Procedures, Westinghouse } \\
\text { Hanford Company, Richland, Washington }\end{array}$ \\
\hline WHC-CM-6-1 & $\begin{array}{l}\text { Standard Engineering Practices, Westinghouse Hanford } \\
\text { Company, Richland, Washington }\end{array}$ \\
\hline WHC-CM-6-3 & $\begin{array}{l}\text { Drafting Standards Manual, Westinghouse Hanford } \\
\text { Company, Rich7and, Washington }\end{array}$ \\
\hline WHC-EP-0550 & $\begin{array}{l}\text { Tank SY-101 Hydrogen Mitigation Test Project Plan } \\
\text { Proposal }\end{array}$ \\
\hline WHC-SD-WM-WP-228 & $\begin{array}{l}\text { Evaluation and Prel iminary Work Plan for Void Fraction } \\
\text { Device }\end{array}$ \\
\hline WHC-SD-WM-WP-259 & $\begin{array}{l}\text { SY-101 In Situ Void Fraction Instrument Engineering } \\
\text { Work Plan, K. L. Pearce and T. I. Stokes, December 1993 }\end{array}$ \\
\hline WHC-SD-WM-HC-010 & $\begin{array}{l}\text { Hazard Classification Study for the SY-101 Tank and } \\
\text { Vicinity of 200 West-241-SY Tank Farm, R. M. Merriman, } \\
\text { et al., March 1994 }\end{array}$ \\
\hline WHC-CM-4-11 & $\begin{array}{l}\text { ALARA Program Manual, Westinghouse Hanford Company, } \\
\text { Richland, Washington }\end{array}$ \\
\hline WHC-CM-1-6 & $\begin{array}{l}\text { WHC Radiological Control Manual, Westinghouse Hanford } \\
\text { Company, Richland, Washington }\end{array}$ \\
\hline
\end{tabular}

\subsection{LOS ALAMOS NATIONAL LAB}

\begin{tabular}{|l|l|}
\hline LA-UR-92-3196 & $\begin{array}{l}\text { A Safety Assessment for Proposed Pump Mixing Operation } \\
\text { to Mitigate Episodic Gas Releases in Tank 241-SY-101: } \\
\text { Hanford Site, Richland, Washington, Rev. 6, L. H. } \\
\text { Sul7ivan }\end{array}$ \\
\hline
\end{tabular}




\subsection{CODES AND STANDARDS}

\begin{tabular}{|l|l|}
\hline ANSI & $\begin{array}{l}\text { Design Criteria for Decommissioning of Nuclear Fuel } \\
\text { Processing PTant, ANSI N300, American National } \\
\text { Standards Institute, Washington, D. C. }\end{array}$ \\
\hline NFPA 70 & $\begin{array}{l}\text { National Fire Protection Association, Batterymarch } \\
\text { Park, Quincy, Massachusetts }\end{array}$ \\
\hline NFPA 497A & $\begin{array}{l}\text { Recommended Practice for Classification of Class 1 } \\
\text { Hazardous (Classified) Locations for Electrical } \\
\text { Instal1ations in Chemical Process Areas }\end{array}$ \\
\hline
\end{tabular}

\subsection{ACRONYMS AND ABBREVIATIONS}

$\begin{array}{ll}\text { ALARA } & \text { As Low As Reasonably Achievable } \\ \text { ANSI } & \text { American National Standards Institute } \\ \text { ASME } & \text { American Society of Mechanical Engineers } \\ \text { B\&PV } & \text { Boiler and Pressure Vessel } \\ \text { DACS } & \text { Data Acquisition and Control System } \\ \text { DBA } & \text { Design Basis Accident } \\ \text { DBE } & \text { Design Basis Earthquake } \\ \text { DCG } & \text { Derived Concentration Guide } \\ \text { DOE } & \text { U.S. Department of Energy } \\ \text { DOT } & \text { U.S. Department of Transportation } \\ \text { FDC } & \text { Functional Design Criteria } \\ \text { GRE } & \text { Gas Release Event } \\ \text { HEPA } & \text { High Efficiency Particulate Air } \\ \text { HPS } & \text { Hanford Plant Standards } \\ \text { I/O } & \text { Input/Output } \\ \text { LANL } & \text { Los Alamos National Laboratory } \\ \text { LFL } & \text { Lower Flammability Limit }\end{array}$




$\begin{array}{ll}\text { NFPA } & \text { National Fire Protection Association } \\ \text { OSHA } & \text { Occupational Safety and Health Administration } \\ \text { PNL } & \text { Pacific Northwest Laboratory } \\ \text { psi } & \text { Pounds per square inch } \\ \text { QA } & \text { Quality Assurance } \\ \text { QAPP } & \text { Quality Assurance Program Plan } \\ \text { RCRA } & \text { Resource Conservation and Recovery Act } \\ \text { RL } & \text { U.S. Department of Energy, Richland Operations Office } \\ \text { SA } & \text { Safety Assessment } \\ \text { SAR } & \text { Safety Analysis Report } \\ \text { USQ } & \text { Unreviewed Safety Question } \\ \text { WHC } & \text { Westinghouse Hanford Company } \\ \text { WISHA } & \text { Washington Industrial Safety and Health Act }\end{array}$

